\title{
The Perception of Stress among Clinical Dental Students
}

\author{
Khalid H Al-Samadani, Ayman Al-Dharrab
}

\begin{abstract}
Objective: To determine the prevalence of stress among clinical students from Faculty of Dentistry, King Abdul Aziz University, Jeddah.
\end{abstract}

Materials and methods: A cross-sectional descriptive study was carried out in May 2012 on fourth, fifth and sixth year clinical dental students from Faculty of Dentistry, King Abdul Aziz University, Jeddah, using a modified form of dental environment stress (DES) questionnaire. A total of 353 questionnaires were distributed and incomplete questionnaires were excluded from the study. SPSS version 15 was used to do statistical analysis.

Results: A total of 353 students were asked to complete the questionnaire and 232 (65.7\%) responded; of these 120 (51.7\%) were males and remaining $112(48.3 \%)$ were females. More or less all the students were having stress. In male students severe stress was due to difficulty in getting suitable patient (51\%) and the patient who were arriving late or not coming on appointment, $p=0.16$, whereas in female they were having severe stress due to fear of failure (59\%), $p=0.02$, examination and grading (57\%) and completing examination requirement (52\%). In male, amount of academic overload was also main cause of severe stress $(p=0.03)$. Sixth-year students were having more stress due to amount of overload (59.1\%), lack of time to do assigned work (53.4\%), difficulty to get suitable patient $(71.6 \%)$ and patient arriving late or not coming on appointment (64.8\%). Fifth-year students were more stressed due to completing examination requirement $(65.7 \%)$. Fourth-year students were having more stress due to fear of failure (58.4\%) and examination and grading (58.4\%).

Conclusion: The finding of this study show some considerable degree or severe stress among the students. Longitudinal studies that include preclinical dental students should be carried out to know how the pattern of stress varies during preclinical and clinical training period.

Keywords: Stress, Descriptive study, Responded, Clinical, Dental students, Grading.

How to cite this article: Al-Samadani $\mathrm{KH}, \mathrm{Al}-\mathrm{Dharrab} \mathrm{A}$. The Perception of Stress among Clinical Dental Students. World J Dent 2013;4(1):24-28.

Source of support: Nil

Conflict of interest: None declared

\section{INTRODUCTION}

Stress is defined as the perception of discrepancy between environment demands and individual capacities to fulfill these demands. Stress develops due to excessive pressure or different types of demands placed on them. ${ }^{1}$ A number of studies on academic stress among students were previously conducted. Some identified the development of stress because of too many assignments, competition with other students, fear of failure, poor relationship with other students or teachers, family problems, frequent examinations, phobia from examinations, demanding curricula, anxious patients, complicated treatments and possible conflicts with patients and limited time to perform and finish the planned treatment. ${ }^{2}$ Stressors vary by individual attitude, beliefs and cultural background. ${ }^{3}$ Dental students from Spain were more stressed by clinical training and performance pressure; whereas Greek students were having more stress during patient treatment. ${ }^{4,5}$ The most important source of stress among Indian dental students was the academic component of the course, especially in regard to examination and grading. ${ }^{5}$

Dental schools are known to be highly demanding with a stressful learning environment. Stress can result physical and psychological distress, which leads to affect the performance of the student. It can cause anxiety, depression, phobia, fear, tension dizziness, fatigue, sleeplessness, gastrointestinal disturbance, irritability and cynicism. ${ }^{6}$ Dental curricula require students to attain diverse proficiencies including acquisition of theoretical knowledge, clinical competencies and interpersonal skills. ${ }^{7}$ The people living in Saudi Arabia are composed from multiple sociocultural backgrounds, hence, they differ fundamentally from each other and, possibly, from other countries. The dental educational system in Saudi Arabia is a hierarchical system, in which there is an initial preparatory year followed by 5 years of dental schooling in which the first 2 years include the basic sciences in medicine and dentistry. During the third year students are exposed to the clinical environment and the fourth and fifth years are mainly clinically oriented. This is followed by a 1 year of internship that involves the students to rotate among different government dental clinics for exposure and practice. ${ }^{6}$ Faculty of Dentistry, King Abdulaziz University, preparatory year is called first year. Previously, dental schools were only located in the major cities (Riyadh, Jeddah and Dammam). Currently, the number of universities that provide dental education has increased significantly. In past, studying dentistry meant that students may have to move away from home and face difficulties in maintaining social ties in with their home towns and building new ones in their new environment. ${ }^{6}$ This has changed due to availability of dental schools closer to their hometowns. Therefore, the study of dentistry in Saudi Arabia may pose different kinds of problems and stress-inducing factors as compared to past 
The Perception of Stress among Clinical Dental Students

that may require further study. This study may provide academic staff and administrator's options to reduce stress among students.

The objective of this study was to investigate the stress among dental students who are clinically involved at the Faculty of Dentistry, King Abdulaziz University, Jeddah, Saudi Arabia. The specific aims are: (1) Study the prevalence of stress among fourth, fifth and sixth year students and (2) determine possible factors that could be responsible.

\section{MATERIALS AND METHODS}

A cross-sectional descriptive study was carried out on fourth, fifth and sixth year dental students from Faculty of Dentistry, King Abdul Aziz University, Jeddah, using a modified form of dental environment stress (DES) questionnaire. The DES consists of 29 close-ended questions in the English language that was applicable to Saudi dental students. Each question had three options: (1) No stress, (2) mild to moderate stress and (3) severe stress.

The questionnaires were distributed during lectures for each year and students were asked to submit the completed questionnaire the following day. Since, stress among dental students has been shown to vary over the course of academic year, so the questionnaires were distributed at the beginning of the first semester. A total of 353 questionnaires were distributed among fourth, fifth and sixth year dental students. Incomplete questionnaires were excluded from the study. Ethical permission was obtained from the Research ethics Committee of the Faculty of Dentistry, King Abdulaziz University. Students were instructed not to write their name to ensure anonymity and confidentiality.

The statistical package for social sciences (SPSS) version 15 was used to analyze the data. Basic descriptive statistics and Chi-square test was used to analyze and correlate the variables. Significant level was set at $\mathrm{p}<0.05$.

\section{RESULTS}

A total of 353 students were asked to complete the questionnaire and 232 (65.7\%) responded; (Graph 1) of these 120 (51.7\%) were males and remaining 112 (48.3\%)

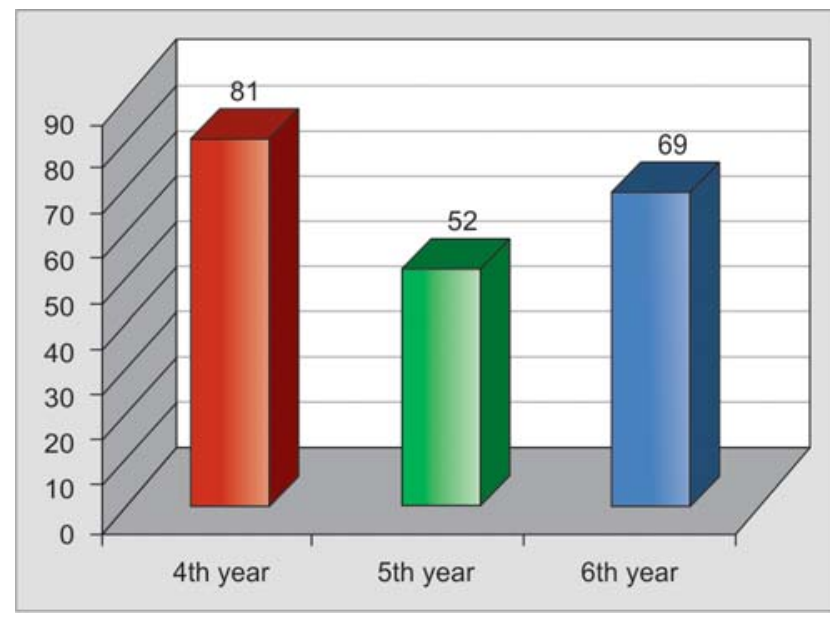

Graph 1: The percentage of clinical students who responded

were females. The maximum number of respondents (81\%) was from fourth year, 52\% respondents were from fifth year and 69\% were from sixth year. Maximum response rate for females was (87\%) from fourth year and the maximum response for males was $76 \%$ from sixth year (Table 1 ).

Table 2 shows the distribution of stress among the respondents and factors that were responsible for severe stress are displayed in descending order.

Table 3 shows the factors which were causing severe stress among more than $40 \%$ of students who were correlated with the gender. In male students severe stress was due to difficulty in getting suitable patients (51\%) and the patient who were arriving late or not coming on appointment but no significant relation were found $(\mathrm{p}=0.16)$, whereas in female they were having severe stress due to fear of failure (59\%) and there was significant relation with the male $(p=0.02)$, examination and grading (57\%) and completing examination requirement (52\%) but there was no significant relation. In male, amount of academic overload was also main cause of severe stress and it was having significant relation with the female $(\mathrm{p}=0.03)$.

Factors causing maximum stress by different years of study are in the Table 4. Sixth-year students were having more stress due to amount of overload (59.1\%), lack of time to do assigned work (53.4\%), difficulty to get suitable patient $(71.6 \%)$ and patient arriving late or not coming on appointment (64.8\%). Fifth-year students were more

\begin{tabular}{|c|c|c|c|c|c|}
\hline Year of study & $\begin{array}{l}\text { Total number of } \\
\text { questionnaire distributed } \\
\text { among the students }\end{array}$ & Male students & Female students & Total responded & Responded(\%) \\
\hline 4th year & 95 & 10 & 67 & 77 & 81 \\
\hline 5 th year & 130 & 43 & 24 & 67 & 52 \\
\hline 6 th year & 128 & 67 & 21 & 88 & 69 \\
\hline Total & 353 & 120 & 112 & 232 & 65.7 \\
\hline
\end{tabular}


Table 2: Distribution of stress among clinical dental students

\begin{tabular}{|c|c|c|c|c|c|c|c|}
\hline & \multicolumn{2}{|c|}{ No. stress } & \multicolumn{2}{|c|}{ Mild to moderate stress } & \multicolumn{2}{|c|}{ Severe stress } \\
\hline \multicolumn{2}{|c|}{ S. no. Questionnaires } & \multirow{2}{*}{$\frac{N}{0}$} & \multirow{2}{*}{$\frac{\%}{0}$} & \multirow{2}{*}{$\frac{N}{103}$} & \multirow{2}{*}{$\frac{\%}{44.4}$} & \multirow{2}{*}{$\frac{N}{129}$} & \multirow{2}{*}{$\frac{\%}{55.6}$} \\
\hline 1. & Examination and grading & & & & & & \\
\hline 2. & Amount of academic over load & 0 & 0 & 108 & 46.6 & 124 & 53.4 \\
\hline 3. & Fear of failure & 7 & 3.0 & 106 & 45.7 & 119 & 51.3 \\
\hline & Completing examination requirements & 1 & 0.4 & 118 & 50.9 & 113 & 48.7 \\
\hline & Difficulty to get suitable patients & 3 & 1.3 & 116 & 50.0 & 113 & 48.7 \\
\hline 6. & Lack of time to do assigned work & 6 & 2.6 & 120 & 51.7 & 106 & 45.7 \\
\hline & Patient arriving late or not coming on appointment & 2 & 0.9 & 126 & 54.3 & 104 & 44.8 \\
\hline 8. & Responsibilities for comprehensive patient care & 8 & 3.4 & 147 & 63.4 & 77 & 33.2 \\
\hline & Rules and regulations of the faculty & 4 & 1.7 & 152 & 65.5 & 76 & 32.8 \\
\hline 10. & Conflict with the patients & 6 & 2.6 & 154 & 66.4 & 72 & 31.0 \\
\hline 11. & Fear of getting infectious diseases like HIV, HBV, etc. & 21 & 9.1 & 143 & 61.6 & 68 & 29.3 \\
\hline 12. & Lack of cooperation by patients in clinic and home care & 2 & 0.9 & 163 & 70.3 & 67 & 28.9 \\
\hline & Financial problem & 31 & 13.4 & 167 & 72.0 & 34 & 14.7 \\
\hline & Difficulty in learning clinical procedures & 19 & 8.2 & 187 & 80.6 & 26 & 11.2 \\
\hline 15. & Difficulty with class work & 15 & 6.5 & 191 & 82.3 & 26 & 11.2 \\
\hline 16. & Inconsistency of feedback regarding work & 11 & 4.7 & 195 & 84.1 & 26 & 11.2 \\
\hline 17. & Amount of cheating among dental students & 15 & 6.5 & 193 & 83.2 & 24 & 10.3 \\
\hline 18. & Attitude of faculty toward students & 10 & 4.3 & 200 & 86.2 & 22 & 9.5 \\
\hline 19. & Environment of extracurricular activities & 56 & 24.1 & 154 & 66.4 & 22 & 9.5 \\
\hline 20. & Difficulty in understanding lectures & 3 & 1.3 & 210 & 90.5 & 19 & 8.2 \\
\hline 21. & Receiving criticism about work & 8 & 3.4 & 205 & 88.4 & 19 & 8.2 \\
\hline 22. & Home atmosphere & 81 & 34.9 & 134 & 57.8 & 17 & 7.3 \\
\hline 23. & Competition with class work & 7 & 3.0 & 209 & 90.1 & 16 & 6.9 \\
\hline 24. & Distance and time needed to travel dental college & 101 & 43.5 & 116 & 50.0 & 15 & 6.5 \\
\hline & Social contact with students & 48 & 20.7 & 170 & 73.3 & 14 & 6.0 \\
\hline 26. & Physical health problem & 120 & 51.7 & 100 & 43.1 & 12 & 5.2 \\
\hline & Having children at home & 147 & 63.4 & 75 & 32.3 & 10 & 4.3 \\
\hline & $\begin{array}{l}\text { Lack of confidence about being a successful } \\
\text { dental students }\end{array}$ & 35 & 15.1 & 188 & 81.0 & 9 & 3.9 \\
\hline 29. & Marital problem & 173 & 74.6 & 51 & 22.0 & 8 & 3.4 \\
\hline
\end{tabular}

Table 3: Distribution of maximum stress among genders

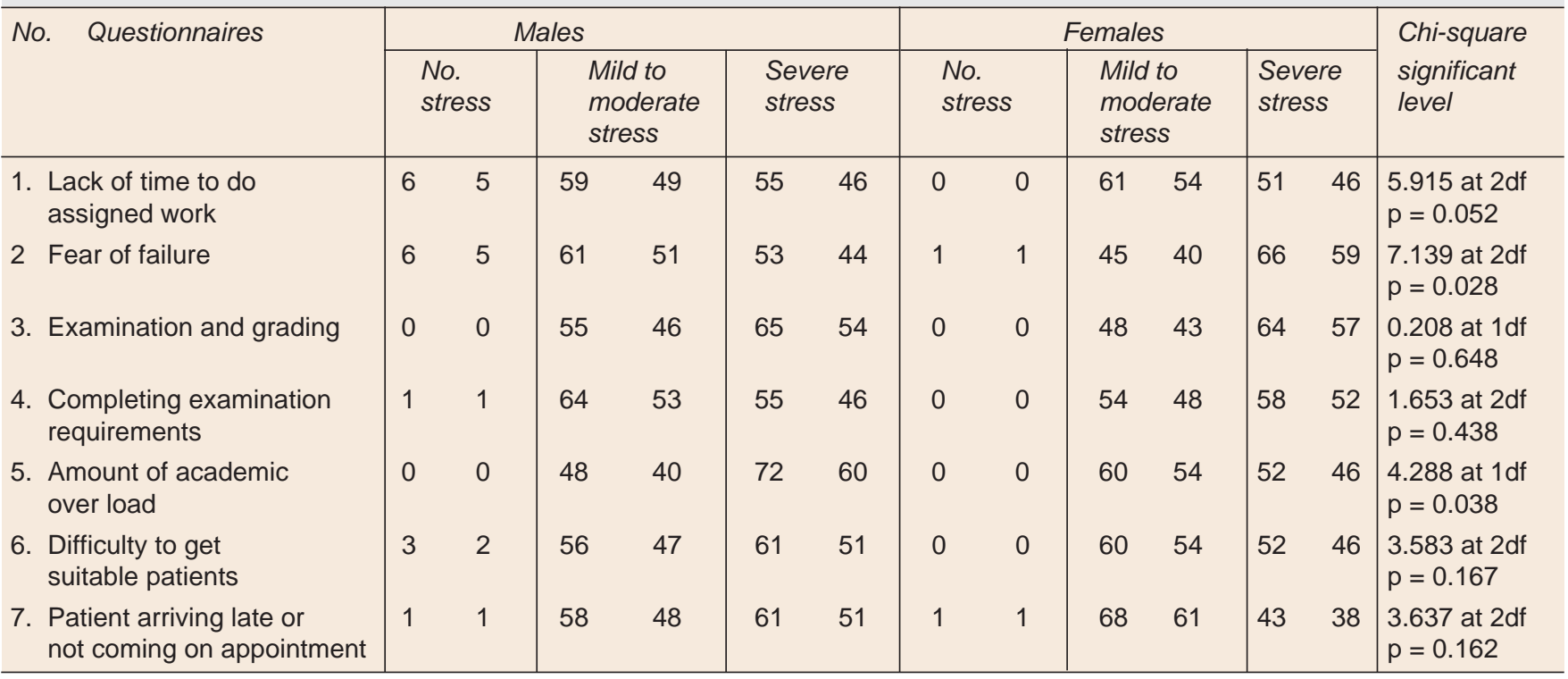

stressed due to completing examination requirement to fear of failure (58.4\%) and examination and grading (65.7\%). Fourth-year students were having more stress due $\quad$ (58.4\%). 
The Perception of Stress among Clinical Dental Students

\begin{tabular}{|c|c|c|c|c|c|c|c|c|}
\hline \multirow{2}{*}{$\begin{array}{l}\text { Questionnaire } \\
\text { Amount of } \\
\text { academic } \\
\text { overload }\end{array}$} & \multirow{2}{*}{$\begin{array}{l}\text { Grade of stress } \\
\text { No stress } \\
\text { Mild to moderate stress } \\
\text { Severe stress }\end{array}$} & \multicolumn{2}{|c|}{ 4th year } & \multicolumn{2}{|c|}{ 5th year } & \multicolumn{2}{|c|}{ 6th year } & \multirow{2}{*}{$\begin{array}{l}\text { Significant level } \\
2.515 \text { at } 3 \mathrm{df} \\
p=0.284\end{array}$} \\
\hline & & $\begin{array}{l}0 \\
41 \\
36\end{array}$ & $\begin{array}{c}0 \\
53.2 \\
46.8\end{array}$ & $\begin{array}{l}0 \\
31 \\
36\end{array}$ & $\begin{array}{l}0 \\
46.3 \\
53.7\end{array}$ & $\begin{array}{l}0 \\
36 \\
52\end{array}$ & $\begin{array}{l}0 \\
40.9 \\
59.1\end{array}$ & \\
\hline Fear of failure & $\begin{array}{l}\text { No stress } \\
\text { Mild to moderate stress } \\
\text { Severe stress }\end{array}$ & $\begin{array}{l}0 \\
32 \\
45\end{array}$ & $\begin{array}{c}0 \\
41.6 \\
58.4\end{array}$ & $\begin{array}{l}1 \\
38 \\
28\end{array}$ & $\begin{array}{l}1.5 \\
56.7 \\
41.8\end{array}$ & $\begin{array}{l}6 \\
36 \\
46\end{array}$ & $\begin{array}{l}6.8 \\
40.9 \\
52.3\end{array}$ & $\begin{array}{l}11.527 \text { at } 4 d f \\
p=0.021\end{array}$ \\
\hline $\begin{array}{l}\text { Examination and } \\
\text { grading }\end{array}$ & $\begin{array}{l}\text { No stress } \\
\text { Mild to moderate stress } \\
\text { Severe stress }\end{array}$ & $\begin{array}{l}0 \\
32 \\
45\end{array}$ & $\begin{array}{c}0 \\
41.6 \\
58.4\end{array}$ & $\begin{array}{l}0 \\
33 \\
34\end{array}$ & $\begin{array}{l}0 \\
49.3 \\
50.7\end{array}$ & $\begin{array}{l}0 \\
38 \\
50\end{array}$ & $\begin{array}{l}0 \\
43.2 \\
46.8\end{array}$ & $\begin{array}{l}0.944 \text { at } 2 d f \\
p=0.624\end{array}$ \\
\hline $\begin{array}{l}\text { Completing } \\
\text { examination } \\
\text { requirement }\end{array}$ & $\begin{array}{l}\text { No stress } \\
\text { Mild to moderate stress } \\
\text { Severe stress }\end{array}$ & $\begin{array}{l}0 \\
46 \\
31\end{array}$ & $\begin{array}{c}0 \\
59.7 \\
40.3\end{array}$ & $\begin{array}{l}0 \\
23 \\
44\end{array}$ & $\begin{array}{l}0 \\
34.3 \\
65.7\end{array}$ & $\begin{array}{l}1 \\
49 \\
38\end{array}$ & $\begin{array}{l}1.1 \\
55.7 \\
43.2\end{array}$ & $\begin{array}{l}12.471 \text { at } 4 d f \\
p=0.014\end{array}$ \\
\hline $\begin{array}{l}\text { Lack of time to } \\
\text { do assigned work }\end{array}$ & $\begin{array}{l}\text { No stress } \\
\text { Mild to moderate stress } \\
\text { Severe stress }\end{array}$ & $\begin{array}{l}0 \\
45 \\
32\end{array}$ & $\begin{array}{c}0 \\
58.4 \\
41.6\end{array}$ & $\begin{array}{l}2 \\
38 \\
27\end{array}$ & $\begin{array}{l}3.0 \\
56.7 \\
40.3\end{array}$ & $\begin{array}{l}4 \\
37 \\
47\end{array}$ & $\begin{array}{l}4.5 \\
42.0 \\
53.5\end{array}$ & $\begin{array}{l}7.789 \text { at } 4 d f \\
p=0.100\end{array}$ \\
\hline $\begin{array}{l}\text { Difficulty to get } \\
\text { Suitable patients }\end{array}$ & $\begin{array}{l}\text { No stress } \\
\text { Mild to moderate stress } \\
\text { Severe stress }\end{array}$ & $\begin{array}{l}0 \\
56 \\
21\end{array}$ & $\begin{array}{c}0 \\
72.7 \\
27.3\end{array}$ & $\begin{array}{l}2 \\
36 \\
29\end{array}$ & $\begin{array}{l}3.0 \\
53.7 \\
43.3\end{array}$ & $\begin{array}{l}1 \\
24 \\
63\end{array}$ & $\begin{array}{l}1.1 \\
27.3 \\
71.6\end{array}$ & $\begin{array}{l}36.857 \text { at } 4 d f \\
p=0.000\end{array}$ \\
\hline $\begin{array}{l}\text { Patients arriving } \\
\text { late or not coming } \\
\text { on appointment }\end{array}$ & $\begin{array}{l}\text { No stress } \\
\text { Mild to moderate stress } \\
\text { Severe stress }\end{array}$ & $\begin{array}{l}0 \\
61 \\
16\end{array}$ & $\begin{array}{c}0 \\
79.2 \\
20.8\end{array}$ & $\begin{array}{l}1 \\
35 \\
31\end{array}$ & $\begin{array}{l}1.5 \\
52.2 \\
46.3\end{array}$ & $\begin{array}{l}1 \\
30 \\
57\end{array}$ & $\begin{array}{l}1.1 \\
34.1 \\
64.8\end{array}$ & $\begin{array}{l}34.299 \text { at } 4 d f \\
p=0.000\end{array}$ \\
\hline
\end{tabular}

\section{DISCUSSION}

The prevalence of stress was present among all the students for all fourth, fifth and sixth year and they suffered high degree of emotional stress. Previous study from seven European dental schools was reported. Only 22\% students suffer from severe stress while this study showed high degree of severe stress in more than $50 \%$. The cause of stress did vary by years of study and gender. The first major cause of severe stress among dental students was tension of examination and grading (55.6\%) followed by amount of academic overload (53.4\%) and fear of failure (51.3\%) as shown in Table 2. Total course of dentistry is of 6-year duration, first year predental, second and third year preclinical and fourth, fifth and sixth year clinical. Each year is further divided into the two semesters of each 6 months. They have to pass through a lot of test. The academic overload is due to short semester coupled with too many assignments, tests and preparation of final semester examination. Above with these they have to fulfill clinical quota. They cited too many works to be accomplished with short time that leave them with no time to enjoy their social life. Results of this study are consistent with the other studies. ${ }^{1-3,5,8}$ Examination and grading as well as fear of failure are a reflection of academic overload which was not fulfilled in the short period. ${ }^{9}$ This is consistent to other earlier studies that identified fear of failing and poor performance as stressful. ${ }^{1,5,10,11}$

Three factors which were associated with severe stress to females were related to the scarcity of time to complete examination requirement and these were giving to much stress. The lack of time could be attributed to them getting married earlier and even having children while completing their studies. This increased their responsibilities and prevented them from spending much time on their studies. Some researchers had reported similar observation ${ }^{3,10,12-14}$ while others did not find gender differences in perceived stress. ${ }^{15-17}$

In this study, males reported severe stress being caused by the amount of academic overload (60\%) ( $p=0.038)$, difficulty in getting patients and the patients arriving late or not coming for their appointments. This is a common problem worldwide, where females tend to attend and seek medical and dental services more frequently compared to their male counterparts. ${ }^{5,18,19}$ The male patients could be fearful and hence reluctant to attend for treatment, possibly do not want to have treatment done by students and prefer to be treated by a specialist. When patients first arrive at the dental clinic, they are screened by a dentist and then referred to a student for the respective treatment. When patients become aware that students will render the treatment, they became fearful and stopped coming to future visits. ${ }^{6,8}$

The amount of severe stress varied among the different years of study. Fourth-year students were more tensed due to fear of failure and examination grading. ${ }^{5,6,14}$ This could be the initial exposure of these students to the clinics and having to simultaneously deal with both academic and clinical requirements. This could have created an overload 
which resulted in a lack of preparation for examinations and assignments. Fifth-year students were recording most stress reading the inability to complete assignments. This could be as a result of them treating many patients and having a lack of time. Sixth-year students were more worried due to difficulty in getting suitable patients and patients not keeping up with their appointments which prevented them from accomplishing their clinical quotas. ${ }^{20}$

\section{CONCLUSION}

The finding of this study showed that dental students from the faculty of dentistry, King Abdulaziz University, suffered some considerable degree or severe stress. Longitudinal studies that include preclinical dental students should be carried out to know how the pattern of stress varies during preclinical and clinical training period. Time to time analytical study should be carried out to determine the cause and factors related to severe stress. Curricula of the dental school as well as examination pattern should be amended and improved to overcome much stress. Before appointment to the students, patients should be provided proper information regarding appointment, oral health education and students supervision by the consultant not to avoid appointment with the patient or absent on appointment.

\section{REFERENCES}

1. Agolla JE, Ongori H. An assessment of academic stress among undergraduate students: The case University of Botswana. Educ Res Rev 2009;4(2):63-70.

2. Fairbrother K, Warn J. Work place, dimension, stress and job satisfaction. J Managerial Psychol 2003;18(1):8-21.

3. Acharya S. Factors affecting stress among Indian dental students. J Dent Educ 2003;67:1140-48.

4. Polychronopoulou A, Divaris K. Dental students' perceived sources of stress: A multi-country study. J Dent Edu 2009;73(5):631-39.

5. Kumar S, Dagli RJ, Mathur A, Jain M, Prabu, Kulkarni S. Perceived sources of stress amongst Indian dental students. Europ J Dent Educ 2009;13:39-45.

6. Al-Saleh SA, Al-Madi EM, Al-Angari NS, Al-Shehri HA, Shukri MM. Survey of perceived stress-inducing problems among dental students, Saudi Arabia. Saudi Dent J 2010;22:83-88.

7. Polychronopoulou A, Divaris K. Perceived sources of stress among Greek dental students. J Dent Edu 2005;69(6):687-92.
8. Amin WM, Al-Ali MH, Duaibis RB, Oweis T, Badran DH. Burnout among the clinical dental students in the Jordanian Universities. J Clin Med Res 2009;1(4):207-11.

9. Topper EF. Stress in the library work place. New Library World 2007;11(12):561-64.

10. Polychronopoulou A, Divaris K. Dental students' a longitudinal study of Greek dental students' perceived sources of stress. Int Dent J 2010;74(5):524-30.

11. Rajab L. Perceived sources of stress among dental students at the University of Jordan. J Dent Educ 2001;65:232-41.

12. Habeeb KA. Prevalence of stressors among female medical students, Taibah University. J Taibah Univ Med Sc 2010;5(2):106-15.

13. Pohlmann K, Jonas I, Ruf S, Harzer W. Stress, burnout and health in the clinical period of dental education. Eur J Dent Educ 2005;9:78-84.

14. Sugiaura G, Shinada K, Kawaguchi Y. Psychological well being and perceptions of stress amongst Japanese dental students. Eur J Dent Educ 2005;9(1):17-25.

15. Muirhead V, Locker D. Canadian dental students' perceptions of stress and social support. Eur J Dent Educ 2008;12(3): $144-48$.

16. Sofola OO, Jeboda SO. Perceived sources of stress in Nigerian dental students. Eur J Dent Educ 2006;10(1):20-23.

17. Al-Omari WM. Perceived sources of stress within a dental educational environment. J Contemp Dent Pract 2005;6(4): 64-74.

18. Ahmad MS, Md Yusoff MM, Razak IA. Stress and its relief among undergraduate dental students in Malaysia. Southeast Asian J Trop Med Public Health 2011;42(11):996-1004.

19. Calaguas GM. Curriculum and sex-specific differences in academic stress arising from perceived expectations. Int J Human Soc Sci 2011;6(1):63-66.

20. Gorter R, Freeman R, Hammen S, Murtomaa H, Blinkhorn A, Humphris G. Psychological stress and health in under-graduate dental students: Fifth-year outcomes compared with first-year baseline results from five European dental schools. Eur J Dent Educ 2008;12(2):61-68.

\section{ABOUT THE AUTHORS}

\section{Khalid H Al-Samadani}

Assistant Professor and Consultant, Department of Restorative Dental Science, College of Dentistry, Taibah University, Madinah al-Munawwarah, Kingdom of Saudi Arabia

\section{Ayman Al-Dharrab (Corresponding Author)}

Assistant Professor and Consultant, Department of Oral and Maxillofacial Rehabilitation, Faculty of Dentistry, King Abdulaziz University, Jeddah 21589, Kingdom of Saudi Arabia e-mail: aaldharab@kau.edu.sa 